\title{
CERTAIN UNUSUAL RADIOLOGICAL APPEARANCES IN THE CHEST OF COAL-MINERS SUFFERING FROM RHEUMATOID ARTHRITIS
}

\author{
BY \\ ANTHONY CAPLAN \\ From the Cardiff Pneumoconiosis Medical Panel
}

(RECEIVED FOR PUBLICATION AUGUST 8,1952 )

Some two years ago it was observed that the incidence of massive shadows in chest radiographs of coal-miners suffering from rheumatoid arthritis appeared to be unduly high. The observation was thought to warrant further investigation.

From June, 1950, to April, 1952, of about 14,000 claimants for pneumoconiosis disablement benefit seen at the Cardiff Pneumoconiosis Medical Panel, 51 were found on examination to be suffering from rheumatoid arthritis, an incidence of about $0.4 \%$. The original impression of the high incidence of massive shadows in arthritics was confirmed in that about $90 \%$ of the 51 cases showed massive fibrosis. This compares with an incidence of about $30 \%$ of massive fibrosis in all men examined. It was also noticed that in about $25 \%$ of the arthritics the radiological opacities in the chest were of a peculiar type and often easily distinguishable from the usual appearances of progressive massive fibrosis (P.M.F.) (Fletcher, 1948). No reference has been found in the literature to this unusual radiological appearance, and this paper is presented with the object of drawing attention to the lung changes associated with rheumatoid arthritis in coal-miners.

The Characteristic Radiological Appearance

The characteristic feature is the presence of multiple, well-defined, round opacities, 0.5 to $5 \mathrm{~cm}$. in diameter, distributed throughout both lung fields but particularly at the periphery (Figs. 1-3). An important finding in these cases is that the background of simple pneumoconiosis is often slight or absent (category* 1 or 0 ). Evidence is also available that the opacities appear rapidly, that is, within months, and tend to remain stationary in most but not all cases.

The differences between these appearances and those seen in progressive massive fibrosis are

\footnotetext{
* Categories of simple pneumoconiosis as defined by Fletcher Mann, Davies, Cochrane, Gilson, and Hugh-Jones (1949): category $1=$ minimal, category 2 =moderate, category $3=$ marked. Category 0 is not defined. It is read when specific dust opacities are either absent or sparser than in the standard (P.R.U.) category 1 film.
}

TABLE I

DIFFERENCES BETWEEN RADIOGRAPHIC APPEARANCES OF CHARACTERISTIC "RHEUMATOID" OPACITIES AND PROGRESSIVE MASSIVE FIBROSIS*

\begin{tabular}{|c|c|c|}
\hline $\begin{array}{l}\text { R adiographic } \\
\text { Appearance } \\
\text { of Opacities }\end{array}$ & "Rheumatoid" & $\begin{array}{l}\text { Progressive } \\
\text { Massive } \\
\text { Fibrosis }\end{array}$ \\
\hline Shape and size & $\begin{array}{l}\text { Round, well defined, } \\
\text { homogeneous density, } \\
\text { commonly } 1 \mathrm{~cm} \text {. diam- } \\
\text { eter (extremes } 0 \cdot 5- \\
5 \mathrm{cn} . \text {.) }\end{array}$ & $\begin{array}{l}\text { Early: irregular, indefin- } \\
\text { ite outline, heterogen- } \\
\text { eous density } \\
\text { Late: round or oval, well } \\
\text { defined, homogeneous. } \\
\text { Almost any size up to } \\
\text { involvement of whole } \\
\text { lobe }\end{array}$ \\
\hline Distribution. . & $\begin{array}{l}\text { Throughout lung fie:ds; } \\
\text { left as frequently as } \\
\text { right; typically peri- } \\
\text { pheral at junction of } \\
\text { outer and middle } \\
\text { thirds }\end{array}$ & $\begin{array}{l}\text { More commonly right } \\
\text { lung field than left; } \\
\text { usually upper zones, } \\
\text { less frequently mid and } \\
\text { lower zones }\end{array}$ \\
\hline Number & Multiple & $\begin{array}{l}\text { Often single in early case; } \\
\text { rarely more than two } \\
\text { or three in each lung } \\
\text { field }\end{array}$ \\
\hline $\begin{array}{l}\text { Background of } \\
\text { simple pneu- } \\
\text { moconiosis }\end{array}$ & $\begin{array}{l}\text { In about } 45^{\circ} \% \text { of cases } \\
\text { category } 1 \text { or less }\end{array}$ & $\begin{array}{l}\text { Almost invariably cate- } \\
\text { gory } 2 \text { or } 3\end{array}$ \\
\hline $\begin{array}{l}\text { R apidity of } \\
\text { development } \\
\text { and progres- } \\
\text { sion }\end{array}$ & $\begin{array}{l}\text { Relatively sudden; opa- } \\
\text { cities often remain } \\
\text { stationary but occa- } \\
\text { sionally increase in size }\end{array}$ & $\begin{array}{l}\text { Slow, often years; masses } \\
\text { increase in size and } \\
\text { other areas of P.M.F. } \\
\text { appear subsequently }\end{array}$ \\
\hline
\end{tabular}

*These are illustrated diagrammatically by line drawings on pag: 31 .

summarized in Table I. In contrast to the " rheumatoid" opacities the opacities of P.M.F. are, in the early stages, not well defined, more irregular in outline, larger, rarely more than two in number in each lung field, and commonly in the right upper zone. In addition, Fletcher and others (1949) have observed that P.M.F. almost never develops until the background of simple pneumoconiosis is that of category 2. Further, P.M.F. develops and increases slowly over a period of years. Ultimately the opacities become well defined, round, or oval, and may occupy as much as the whole of a lobe.

It is not suggested that all coal-miners with pneumoconiosis and rheumatoid arthritis show the characteristic radiological appearance. Indeed, this 


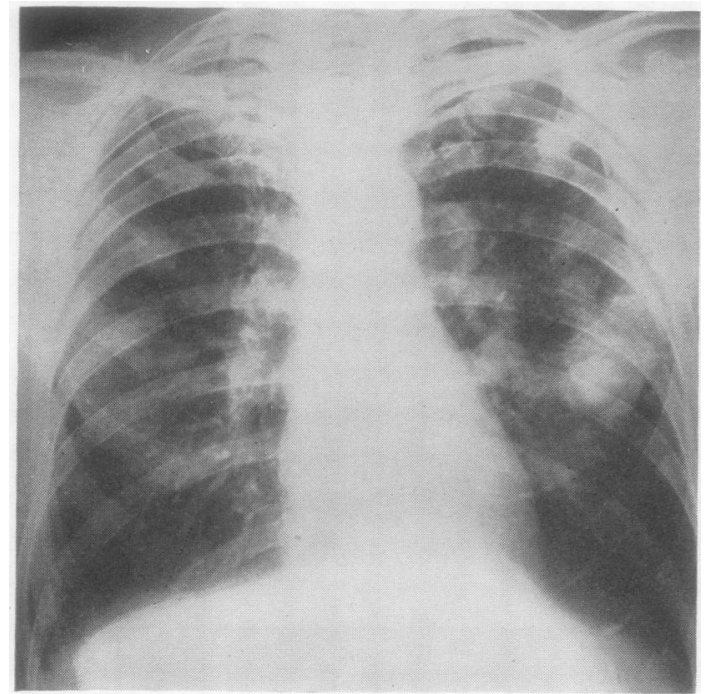

FIG. 1.

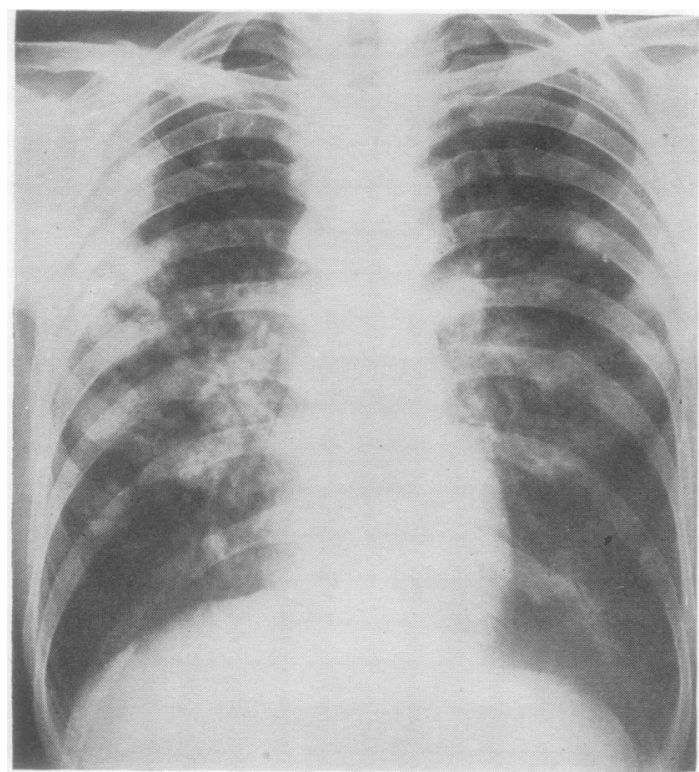

FIG. 2 .

picture was found in only 13 of the 51 cases. Neither is it suggested that all round opacities in the chest in coal-miners are associated with arthritis. Seven of the 51 cases showed only typical P.M.F. lesions. (All, incidentally, had a background of category 3 simple pneumoconiosis.) Twenty-one cases were classified as " mixed," that is, a combination, in varying degree, of opacities indistinguishable

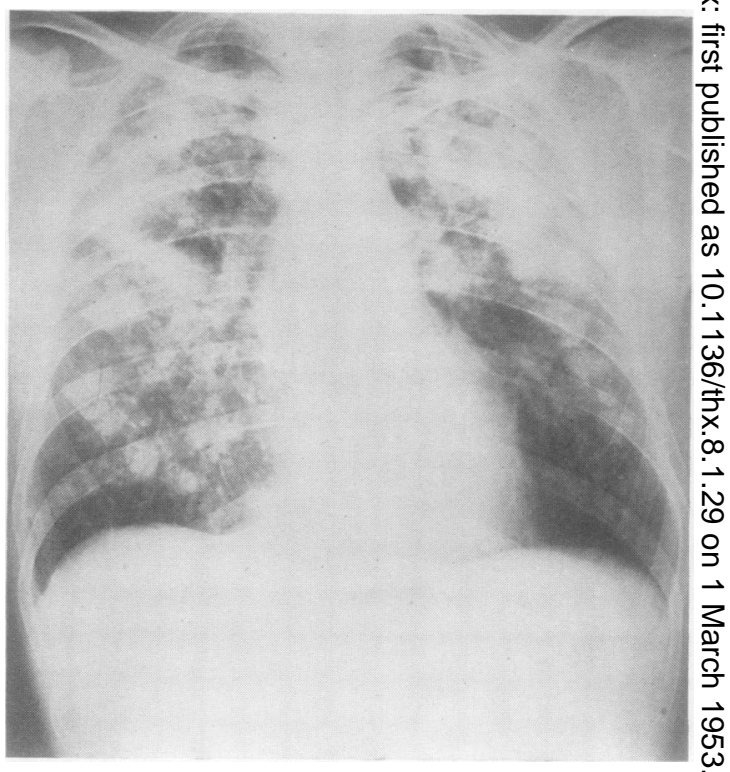

FIG 3.

Figs. 1-3 (Cases 6, 14, and 1).-Radiographs showing three examples of the characteristic " rheumatoid" opacities. The shape, peripheral distribution, and multiplicity of the opacities, combined with the s!ight degree of simple pneumoconiosis, dis-o bined with the s!ight degree of simple pneumoconiosis, dis-
tinguish this type of lesion from ordinary progressive massive tinguish this type of lesion from ordinary progressive massiv
fibrosis. Compare also the diagrams on page 31 and Table I
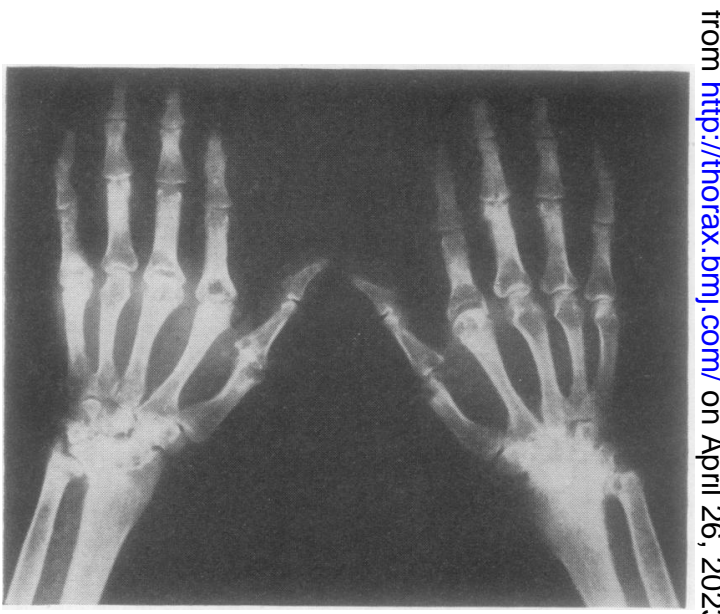

FiG. 4 (Case 16).-Radiograph of both hands and wrists showing loss or disappearance of joint spaces and areas of circumscribed bone rarefaction

from ordinary P.M.F., atypical P.M.F., and the $\frac{\mathbb{Q}}{\mathbb{D}}$ more characteristic round opacities.

In six cases the radiological opacities were 0 indistinguishable from unmodified pulmonary tuberculosis, and two other cases (one "characteristic" 유 and one "mixed") showed areas highly suspicious $\underset{\mathbb{Q}}{\mathbb{Q}}$ of tuberculosis. In addition about $20 \%$ of all cases $\overline{0}$ had apical opacities suggesting the presence of an 

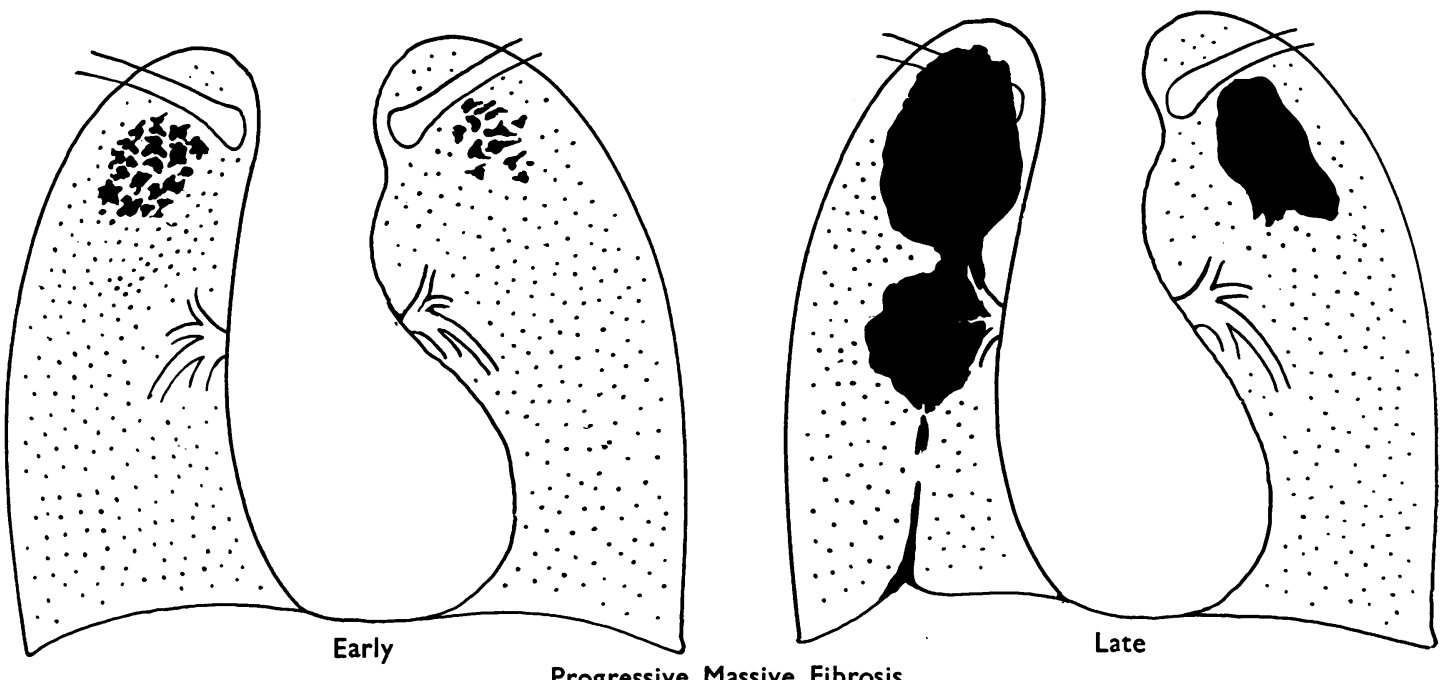

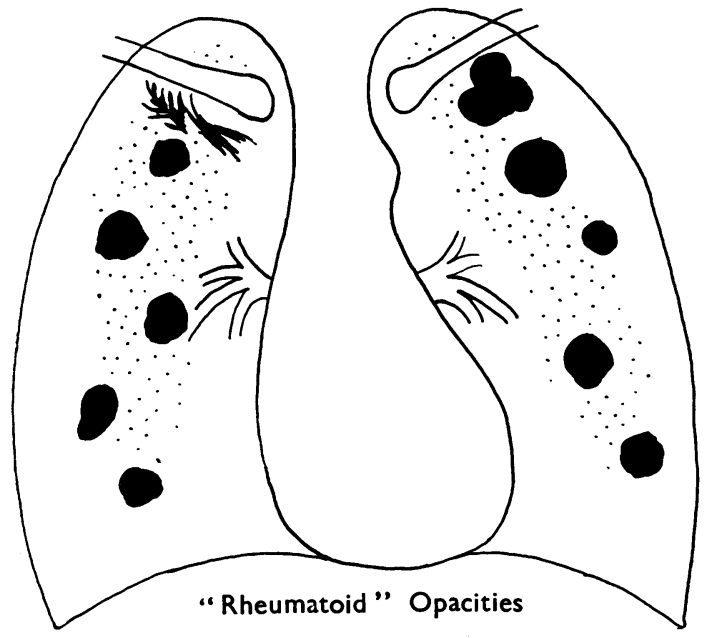

inactive tuberculous lesion. Only four of the 51 cases (including two with classical silicosis) showed simple pneumoconiosis alone. Four cases showed central calcification in the opacities, which is rather uncommon in P.M.F.

\section{THE JOINT LESIONS}

A diagnosis of rheumatoid arthritis was made when there was a history of a recurring polyarthritis which included the hands, and clinical evidence of joint swelling at the time of examination. In most cases the diagnosis had been confirmed by rheumatologists, and many patients had received institutional treatment. Typical rheumatic nodules over the olecranon were present in about one-quarter of the cases. The radiological joint changes in the carpus and phalanges were considered by experts to be typical of rheumatoid arthritis (Fig. 4).

The severity of the joint lesions as judged by the number of joints involved and interference with normal function was slight in 25 cases $(50 \%)$, moderate in 19 cases $(37 \%)$, and severe in seven cases $(13 \%)$. There appeared to be no relationship between the severity of the joint lesions and the extent and character of the radiological changes in the chest.

\section{The Time Relationship Between ARthritis and Observed Radiological Changes}

In 37 cases the earliest chest radiograph was taken after the onset of arthritis; in 12 within one year, in 14 between two and five years, and in 11 between six and 20 years.

In the other 14 cases the joint lesions occurred after a clinical and radiological examination of the chest had been made. These cases, in which chest radiographs before and after the development of arthritis are available, are set out in Table II, which gives the approximate date of the radiographical examinations in relation to the onset of arthritis, and compares the radiological appearances before and after the onset of arthritis. In eight cases the radiograph was taken one year or less and in six cases two to four years before the arthritis. The background of simple pneumoconiosis in these cases is generally of a higher category than in the whole series.* Only three cases were read as category 1 , four as category 2 , six as category 3 , and one poor-quality film as unreadable. Opacities

\footnotetext{
* A summary of the radiological and clinical findings in the 51 cases is given in the Appendix.
} 
TABLE II

COMPARISON OF PRE- AND POST-ARTHRITIC RADIOGRAPHIC APPEARANCES

\begin{tabular}{|c|c|c|c|c|c|}
\hline \multirow[b]{2}{*}{$\begin{array}{l}\text { Case } \\
\text { No. }\end{array}$} & \multicolumn{3}{|r|}{ Before Arthritis } & \multicolumn{2}{|r|}{ After Arthritis } \\
\hline & Time & $\begin{array}{l}\text { Category of } \\
\text { Simple } \\
\text { Pneumo- } \\
\text { coniosis* }\end{array}$ & Other Opacities & Time & $\begin{array}{l}\text { Alteration in Radiographic } \\
\text { Appearances }\end{array}$ \\
\hline 2 & 9 mths. & $\overrightarrow{\mathrm{U}}$ & Tuberculosis $\mathbf{R}$. mid zone & $2 \mathrm{mths}$ & $\begin{array}{l}\text { Widespread extension } R \text {. upper and mid zone } \\
\text { fluffy opacities } L \text {. upper and mid-zones }\end{array}$ \\
\hline $\begin{array}{r}3 \\
10 \\
12 \\
15\end{array}$ & $\begin{array}{l}8 \\
4 \text { yrs." } \\
2 \text { mihs. } \\
9 \text { mith. }\end{array}$ & $\begin{array}{l}3 \\
2 \\
3 \\
1\end{array}$ & $\begin{array}{l}\text { None } \\
\qquad . . \\
\text { Indefinite apical opacity ? tuberculous }\end{array}$ & $\begin{array}{ll}4 & , \\
8 & , \\
6 & , \\
4 & ,\end{array}$ & $\begin{array}{l}\text { P.M.F. both upper zones } \\
\text { Probable bilateral apical tuberculosis } \\
\text { No change } \\
\text { R. apical opacity much larger; widespread }\end{array}$ \\
\hline $\begin{array}{l}18 \\
19\end{array}$ & $\begin{array}{l}3 \text { yrs. } \\
9 \text { mins. }\end{array}$ & $\begin{array}{l}2 \\
1\end{array}$ & $\begin{array}{l}\text { Indefinite opacity R. mid-zone (P.M.F.) } \\
\text { None }\end{array}$ & $\begin{array}{l}3 \text { yrs. } \\
10 \mathrm{mths}\end{array}$ & $\begin{array}{l}\text { Widespread bilateral round opacities } \\
\text { Sparse round and irregular opacities } L \text {. mid and }\end{array}$ \\
\hline $\begin{array}{l}23 \\
24\end{array}$ & 10 yrs. & 3 & $\begin{array}{l}\text { Small irregular P.M.F. opacity R. apex } \\
\text { None }\end{array}$ & 2 yr. & $\begin{array}{l}\text { Bilateral irregu'ar and round opacities upper and } \\
\text { mid-zone }\end{array}$ \\
\hline 25 & 2, & $\frac{3}{2}$ & $\ddot{,}$ & $\begin{array}{ll}1 & . \\
1 & .\end{array}$ & $\begin{array}{l}\text { Irregular opacity } R \text {. mid-zone } \\
\text { Bilateral irregular and round opacities upper } \\
\text { and mid-zones }\end{array}$ \\
\hline 34 & $\begin{array}{c}11 \mathrm{mths} \\
6 \mathrm{P}\end{array}$ & $\begin{array}{l}1 \\
3\end{array}$ & $\begin{array}{l}\text { Tuberculosis R. upper and mid zones } \\
\text { Irregular opacities R. upper zone; round } \\
\text { opacity L. upper zone (P.M.F.) }\end{array}$ & $\begin{array}{l}1 \mathrm{mth} \text {. } \\
6 \mathrm{mths} \text {. }\end{array}$ & $\begin{array}{l}\text { No change } \\
\text { Opacities larger and more well defined }\end{array}$ \\
\hline 49 & $1 \mathrm{yr}$. & 3 (Si.) & None & 4 yrs. & Central ca'cification in silicotic nodules \\
\hline
\end{tabular}

* The categories of simple pneumoconiosis used are those defined by the Pneumoconiosis Research Unit (Fletcher and others. 1949). U R - unreadable. R. right. L.=left. P.M.F.= progressive massive fibrosis.

other than those due to simple pneumoconiosis were present in six cases and were classified as probable tuberculosis in two cases, doubtful tuberculosis in one case, and P.M.F. in three cases.

Chest radiographs were repeated after the onset of arthritis within one year in 12 cases and in three and four years respectively in the remaining two. Of the 14 cases, 11 showed an alteration in the radiological picture due to the development or spread of round opacities (two cases), P.M.F. (three cases), tuberculosis (two cases), "mixed" type of lesion (three cases), or calcification in pre-existing lesions (one case). The radiological appearances in the remaining three were unaltered.

\section{PROGRESSION}

Up to date only five cases have been under observation for five years or longer. It is therefore unwise to give anything but a preliminary impression of the progress of the lesions. Two cases with " characteristic" round opacities showed an appreciable increase in the size of opacities after intervals of one and five years respectively. As a general rule little or no change has been noticed except when tuberculosis has been suspected. In cases with arthritis of long duration (over 10 years) the opacities appear to be more irregular and often stellate in outline, suggesting that they have shrunk.

\section{Clinical Aspects}

AGE INCIDENCE. - The age incidence in the 51 cases is shown in Table III, where for comparison is also shown the age incidence of 1,000 pneumoconiotics without arthritis. The main difference is
TABLE III

AGE INCIDENCE

A. In 51 Pneumoconiotics with Rheumatoid Arthritis

\begin{tabular}{rcccccccc}
\hline Age (Years) & $\begin{array}{c}\text { Under } \\
30\end{array}$ & $30-9$ & $40-9$ & $50-9$ & $\begin{array}{c}60 \\
\text { and } \\
\text { Over }\end{array}$ & Total \\
\hline $\begin{array}{c}\text { At onset of arthritis } \\
\begin{array}{c}\text { When first examined by } \\
\text { panel }\end{array}\end{array}$ & 6 & 15 & 14 & 13 & 3 & 51 \\
\hline
\end{tabular}

B. In a Random Sample of 1,000 Pneumoconiotics without Arthritis

\begin{tabular}{|c|c|c|c|c|c|c|}
\hline \multirow[t]{2}{*}{ Age (Years) } & & \multicolumn{2}{|c|}{$\begin{array}{l}\text { P.M.F. or } \\
\text { Tuberculosis }\end{array}$} & \multicolumn{2}{|c|}{$\begin{array}{c}\text { Simple } \\
\text { Pneumoconiosis }\end{array}$} & \multirow{2}{*}{$\frac{\text { Total }}{\text { No. }}$} \\
\hline & & No & $\%$ & No. & $\%$ & \\
\hline $\begin{array}{ll}\text { Under } & \ldots \\
30-9 & \ldots \\
40-9 & \ldots \\
50-9 & \ldots \\
60 \text { and over }\end{array}$ & $\begin{array}{l}\ldots \\
\cdots \\
\cdots \\
\cdots \\
. .\end{array}$ & $\begin{array}{r}4 \\
52 \\
95 \\
109 \\
82\end{array}$ & $\begin{array}{r}1 \\
15 \\
28 \\
32 \\
24\end{array}$ & $\begin{array}{r}31 \\
121 \\
206 \\
180 \\
120\end{array}$ & $\begin{array}{r}5 \\
18 \\
31 \\
27 \\
18\end{array}$ & $\begin{array}{r}35 \\
173 \\
301 \\
289 \\
202\end{array}$ \\
\hline & & 342 & 100 & 658 & 99 & 1.000 \\
\hline
\end{tabular}

the much smaller proportion of men aged 60 or $\widetilde{N}$ over in the arthritis group $(8 \%$ compared with $20 \%$ N in the non-arthritic group).

The most noteworthy clinical findings were the apparent absence of constitutional symptoms even when tuberculosis was suspected, and the infrequency of more than slight impairment of respiratory $\stackrel{\mathbb{S}}{\rightarrow}$ function. The only consistent finding suggesting the presence of an infective process was a moderately $\overline{0}$ raised erythrocyte sedimentation rate. The degree $\mathbb{\mathbb { D }}$ of respiratory disablement estimated by a simple $\frac{}{\mathbb{D}}$ exercise test in 47 cases was severe in one, moderate in eight, slight in 20 , and nil in 18 . The degree of 
respiratory disability was related as much to age and the duration of arthritis as to the extent of the radiological opacities.

Specimens of sputa were examined for tubercle bacilli by smear and culture in 23 cases, but with negative results. In one case investigated by the Pneumoconiosis Research Unit at Llandough Hospital tubercle bacilli were isolated from two out of seven gastric lavages. The bacilli were described as being pathogenic but morphologically atypical. In this case a radiograph nine months before the onset of arthritis at the age of 37 showed a small irregular opacity at the right apex, with a background of category 1 pneumoconiosis. Four months after the onset of arthritis the apical opacity was larger, and there were many round opacities in both lungs. A full course of streptomycin and para-aminosalicylic acid caused no change in the radiographic appearances. Eighteen months later the number and size of the opacities had increased, though there were no constitutional symptoms.

FATAL CASES.-There were three fatal cases.

Case 44.-This was a man aged 73. Arthritis began about 13 years before death, and he had been bedridden for many years. A chest radiograph taken by the P.R.U. during the Rhondda Fach Survey about six months before death showed extensive bilateral opacities, mainly of P.M.F. type, with a few discrete, round opacities in the left lower zone. The lungs at necropsy showed masses indistinguishable from P.M.F. and a number of discrete nodules, $1 \mathrm{~cm}$. diameter, which appeared to be encapsulated. There was in addition a small tuberculous cavity in one of the masses with early tuberculous bronchopneumonia. Microscopy of the non-tuberculous lesions showed undifferentiated fibrous tissue.

Case 38.-A man aged 46 had had severe arthritis for 12 years, and had been bedridden for 11 years. A chest radiograph, of poor quality, taken seven months before death on account of melanoptysis, showed P.M.F. in both mid-zones with possible cavities in the right mid-zone. The immediate cause of death was cerebral haemorrhage. The lungs showed sparse silicotic nodules with masses at the bases of both upper lobes. An ischaemic cavity was present in a mass in the right lung. Microscopy showed undifferentiated fibrous tissue in the masses and typical silicotic whorling in the nodules. Human type tubercle bacilli were obtained on culture of material from a massive lesion.

Case 17.-A man then aged 26 was first examined in March, 1950. He had been a collier for 12 years and was still at work. He complained of lassitude, cough, and joint pains of about 18 months' duration; five months before he had once coughed up sputum streaked with blood. There was slight dyspnoea on moderate exertion. His physique was poor (weight $130 \mathrm{lb}$., afebrile, pulse 92). No abnormal physical signs were detected in the chest. Typical subacute rheumatoid arthritis involved fingers, wrists, ankles, and knees. A chest radiograph showed small, medium, and large irregular opacities involving all zones at both lung fields, and a cavity $4 \mathrm{~cm}$. diameter with a fluid level in the right upper zone. Sputa were negative for tubercle bacilli on culture. He was examined again in August, 1951, and stated that the joints had improved after a course of gold injections and that he was working as an underground electrician. His general condition was unchanged (weight $131 \mathrm{lb}$.). The joint lesions were quiescent. A chest radiograph showed that the cavity had filled and the opacities in the left mid-zone were more extensive. He remained at work until May 16, 1952 , when he died suddenly after a large haemoptysis.

The lungs at necropsy showed moderate numbers of soft coal foci and a few palpable infected nodules. There was a large tuberculous cavity in the right upper lobe, an irregular "dust" mass in the right middle lobe, and a spherical mass with an ischaemic cavity in the apex of the lower lobe. A large chronic tuberculous cavity containing blood clot was present in the left upper lobe. The tuberculous nature of the cavities was confirmed by microscopy. The histological findings in the infective nodules and massive fibrosis lesions were similar to those found in complicated pneumoconiosis.

\section{Discussion}

It is obviously of primary importance to establish at the outset that a characteristic and recognizable radiographic appearance does occur in the lungs of coal-miners suffering from rheumatoid arthritis. It may be argued that the cases described in this paper are examples of the coincidental presence in one individual of two common diseases in South Wales, massive pneumoconiosis and rheumatoid arthritis. This may well be so in a small proportion of cases, but the available evidence supports the contention that in the majority of cases the association of the two conditions is more than coincidental.

There is, first, the striking fact that more than $90 \%$ of the 51 miners with rheumatoid arthritis showed radiographic opacities in the chest other than those due to simple pneumoconiosis. The incidence of P.M.F. in all men examined is about $30 \%$; if the diseases were coincidental, a similar proportion of the arthritics should show massing.

Secondly, the radiographic appearances of the massive shadows are often not typical of P.M.F., and in about $25 \%$ of cases there is a distinct difference in the shape, number, and distribution of the opacities, rate of development, and background of simple pneumoconiosis from those seen in P.M.F.

In a subsequent paper it will be shown that it is possible, on the radiographic appearances alone, to select from a large group of films of P.M.F. 
those which are associated with rheumatoid arthritis.

Evidence of the possible presence of this lung lesion in arthritics not exposed to a dust hazard has been sought. Seventy chest radiographs (50 from South Wales and 20 from the London area) of non-miners suffering from rheumatoid arthritis were examined with negative results. Consultations with several rheumatologists confirmed the apparent absence of this type of chest lesion in non-miners. This suggests that the lung lesions are confined to workers exposed to a dust hazard. (One case in a brass foundry worker, not included in this series, has been seen.) If this finding is confirmed, it must be assumed that dust, even in small quantities, is intimately connected with the pathogenesis of the chest lesions.

The puzzling problem is the relationship between the lung and joint lesions. The association of thoracic neoplasms and polyarthritis and the dramatic improvement or even disappearance of the arthritis after removal of the tumour has been recognized for many years (Ellman, 1947). It has also long been known that lung lesions may occur in the collagen group of diseases. Middleton (1951), discussing pulmonary manifestations of systemic diseases, reported two cases of rheumatoid arthritis with pulmonary lesions. Details of the industrial history were not given and the radiographic appearances were not described in detail, but one of the two chest radiographs illustrated appeared to show a round opacity at the extreme right base with irregular opacities in both mid-zones. Respiratory symptoms and signs were stated to be absent in one case and slight in the other.

Ellman and Ball (1948) described three cases of " rheumatoid disease" with joint and pulmonary manifestations. Two patients, a fitter's mate and a cotton-mill worker, showed radiologically " reticular" shadows, a " bronchopneumonic lesion," and "bilateral basal opacities." Toxaemia was severe and death ensued. Histological examination of the lungs showed a "fibrosing pneumonitis." The third patient, a housewife, developed a " miliary mottling" throughout both lung fields and a diagnosis of periarteritis nodosa was suggested. The radiographic appearances in these cases were unlike those described in this paper. Ellman suggested that the joint and lung lesions were manifestations of one and the same pathological process, in both the essential lesion being a " rheumatoid granuloma."

The hypothesis that the round pulmonary lesions described in this paper are "rheumatoid granulomata" and perhaps similar in histology to the olecranon nodule is attractive. On this hypothesis $\stackrel{.}{\Rightarrow}$ it would be reasonable to expect that similar lung lesions would be equally common in non-miners.o It has been suggested that rheumatoid granulomata may, in fact, occur in non-miners but are not $\frac{\bar{\rho}}{2}$ sufficiently radio-opaque to be seen in an ordinary $\mathbb{\varnothing}$ chest radiograph, whereas the granuloma in a miner attracts dust and thereby becomes visible radiologi- cally. This theory would be more acceptable if round opacities were more commonly associated $\overrightarrow{\vec{\omega}}$ with extensive simple pneumoconiosis (category 3 ) $\stackrel{\omega}{\circ}$ and less commonly with an insignificant or negligible $\vec{x}$ degree of pneumoconiosis (category 0 or 1 ).

In order to establish whether a relationship exists between dust inhalation and rheumatoid $\tilde{c}$ arthritis it is necessary to compare the incidence of $\frac{\text { ? }}{3}$ rheumatoid arthritis in miners $(a)$ without pneumo-coniosis, (b) with simple pneumoconiosis, (c) with massive pneumoconiosis and in non-miners. An investigation on these lines is now being pursued $\stackrel{ }{\supset}$ by the Pneumoconiosis Research Unit and will be $\vec{c}$ published later. Lawrence and Aitken-Swan (1952) in an investigation in the Manchester area on 0 rheumatism in coal-miners found that the incidence of rheumatoid arthritis was higher in non-miners than in miners. Confirmation of this finding in other coalfields is necessary.

The true nature of the lung lesion can only be $a \stackrel{2}{\Rightarrow}$ conjecture until biopsy material is obtained from $\frac{3}{3}$ an early case. Efforts to obtain permission for a thoracotomy have so far been unsuccessful. This unwillingness to consent to a biopsy is understandable in claimants for compensation. The problem is unlikely to be solved by post-mortem material from the long-standing arthritic case. For if it is assumed that the lung and joint lesions are 3 . of approximately equal duration, it is to be expected that any "granulomatous" lesion in coal-miners may attract dust and ultimately become fibrotico and indistinguishable histologically and radiologically from ordinary P.M.F.

It is now generally accepted in Great Britain that P.M.F. is a form of tuberculosis modified by . dust. It may well be that the so-called " rheuma- N toid" round lesions are yet another manifestation N of tuberculosis modified by dust with an addedo factor related to the rheumatoid arthritis. The radiological resemblance of the round opacities to tuberculomata is quite striking. The conception of $\stackrel{?}{+}$ the lesions being a modified form of tuberculosis is 0 supported by the little evidence so far available. 0 Although tubercle bacilli have been isolated during life in one case only, the radiographic appearances in others have suggested tuberculosis. The frequent association of P.M.F. and round opacities also 
suggests that they may be of similar pathology. Lastly, conclusive evidence of tuberculosis was found in all three fatal cases.

If the suspicion that the pulmonary lesions are tuberculous is confirmed, the possible relationship between tuberculosis and rheumatoid arthritis will once more need re-examination. Poncet (1902) first suggested in 1897 that rheumatoid arthritis could be tuberculous in origin. Since then there has been much opposition, particularly in Great Britain and the U.S.A., to accept the concept of "tuberculous rheumatism." On the Continent, Poncet's views received greater support, and Reitter and Löwenstein (1930) stated they were able to obtain a positive blood culture for tubercle bacilli in many cases of rheumatoid arthritis. This was confirmed by some workers but not by others (Brav and Hench, 1934). Opinion is divided in the few papers on "tuberculous rheumatism" by British workers (Thomson, 1910; Raw, 1914; Copeman and Clay, 1935; Copeman, 1936; Dickson, 1936). Copeman is the only author who has described a large series (42 "selected" cases) and produces strong evidence (including 11 positive blood cultures by Löwenstein) that in certain cases of rheumatoid arthritis a low-grade tuberculous infection may be related to the "course of the polyarthritis."

Brav and Hench (1934) made a complete review of the extensive literature and discussed the case for and against the concept of tuberculous rheumatism. Reference was made to possible factors in the pathogenesis such as diffusible toxin, attenuated bacilli, ultravirus, trophic forms of the tubercle bacillus, and allergy. They comment:

"It is not unreasonable to believe that a tuberculous infective agent of a somewhat different type, or of altered virulence, might produce in joints or in the lungs microscopic changes which do not possess the characteristic cellular elements and configuration attributed to tuberculosis."

And they conclude:

"At present no incontrovertible proof exists to support the existence of such an entity."

\section{SUMMARY}

Attention is drawn to an association in coalminers of rheumatoid arthritis and unusual radiographic appearances in the chest. Of about 14,000 claimants for pneumoconiosis disablement benefit, 51 were found to be suffering from rheumatoid arthritis. About $90 \%$ of the 51 cases showed massive fibrosis as compared with an incidence of about $30 \%$ of massive fibrosis in all men examined.
In 13 of the 51 cases the radiographic appearances were of a peculiar type and often easily distinguishable from progressive massive fibrosis (P.M.F.) in that the opacities were multiple, round, well defined, and distributed fairly evenly throughout both lung fields, particularly at the periphery. In addition, the background of simple pneumoconiosis was often slight and the lesions developed fairly rapidly. In other cases the radiological appearances resembled P.M.F. (seven cases), tuberculosis (six cases), or a " mixed" type of lesion (21 cases). Only four of the 51 cases showed simple pneumoconiosis alone.

The lesions were not usually associated with constitutional symptoms and respiratory disability was often only slight.

The possible nature of the chest lesion is briefly discussed. A tentative suggestion is made that (a) the lesions are probably allied to tuberculomata and are a form of tuberculosis modified by dust, and (b) the joint changes may be a manifestation of " tuberculous rheumatism."

The problem of the relationship between the chest and joint lesions will remain unsolved until more is known concerning the epidemiology of rheumatoid arthritis, the clinico-pathological changes, and the histological appearance of an early pulmonary lesion. Investigations along these lines are now being made by the Pneumoconiosis Research Unit.

I am indebted to the Chief Medical Officer, Ministry of National Insurance, for permission to publish this paper; to my colleagues at the Cardiff Pneumoconiosis Medical Panel for their interest and help in referring cases; to Drs. C. M. Fletcher, J. C. Gilson, A. L. Cochrane, and W. E. Miall, of the Pneumoconiosis Research Unit, for supplying information of cases under their care, their helpful advice and criticism, and providing facilities for preparing the illustrations; and to Drs. O. Savage and K. Lloyd for their advice and for providing the chest radiographs of non-miners.

\section{REFERENCES}

Brav, E. A., and Hench, P. S. (1934). J. Bone Jt Surg., 16, 839.

Copeman, W. S. C. (1936). Proc. Mayo Clin., 11, 568.

and Clay, R. D. (1935). Lancet, 2, 1460.

Dickson, F. D. (1936). J. Lab. clin. Med., 22, 35.

Ellman, P. (1947). Lancet, 1, 464.

and Ball, R. E. (1948). Brit. med. J., 2, 816.

Fletcher, C. M. (1948). Ibid., 1, $1015,1065$.

- Mann, K. J., Davies, I., Cochrane, A. L., Gilson, J. C., and Hugh-Jones, P. (1949). J. Fac. Radiol., Lond., 1, 40.

Lawrence, J. S., and Aitken-Swan, J. (1952). Brit. J. industr. Med. $9,1$.

Middleton, J. W. (1951). Dis. Chest, 19, 473.

Poncet, A. (1902). Lyon méd., 99, 65.

Raw, N. (1914). Proc. roy. Soc. Med., 7 (Med. Sect.), 68.

Reitter, C., and Löwenstein, E. (1930). Münch. mod. W'schr., 77, 1522. Thomson, A. (1910). Edinb. med. J., n.s., 5, 503. 
A P PENDIX

SUMMARIES OF 51 CASE HISTORIES IN PRESENT SERIES

\begin{tabular}{|c|c|c|c|c|c|c|c|c|c|c|c|}
\hline \multirow[b]{2}{*}{$\begin{array}{l}\text { Case } \\
\text { No. }\end{array}$} & \multicolumn{2}{|c|}{ Age } & \multirow[b]{2}{*}{$\begin{array}{c}\text { Duration } \\
\text { of } \\
\text { Joint } \\
\text { Lesions } \\
\text { (Years) }\end{array}$} & \multirow[b]{2}{*}{ 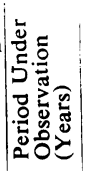 } & \multirow[b]{2}{*}{$\begin{array}{l}\text { Severity } \\
\text { of } \\
\text { Joint } \\
\text { Lesions }\end{array}$} & \multirow[b]{2}{*}{$\begin{array}{l}\text { Respira- } \\
\text { tory } \\
\text { Dis- } \\
\text { ability }\end{array}$} & \multicolumn{4}{|c|}{ Chest Radiological Appearances } & \multirow[b]{2}{*}{ Remarks } \\
\hline & 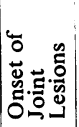 & 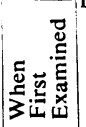 & & & & & $\begin{array}{c}\text { Category } \\
\text { of } \\
\text { Simple } \\
\text { Pneumo- } \\
\text { coniosis }\end{array}$ & $\begin{array}{l}\text { Type of } \\
\text { Massive } \\
\text { Lesion* }\end{array}$ & Distribution & Progression & \\
\hline 1 & 27 & 31 & 10 & 6 & Moderate & S.ight & $\mathbf{U} \mathbf{R}$ & 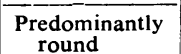 & $\begin{array}{c}\text { All zones } \\
\text { bilateral }\end{array}$ & None & Sputa negativ \\
\hline 2 & 48 & 47 & 2 & 3 & Slight & , & , & Resembles T.B. & $\begin{array}{l}\text { All zones } \\
\mathbf{R}>\mathbf{L}\end{array}$ & $\begin{array}{l}\text { Marked with cav- } \\
\text { ity formation }\end{array}$ &,$\quad$, \\
\hline 3 & 38 & 37 & 2 & 3 & , & None & 3 & P.M.F. & $\begin{array}{l}\text { Sparse upper } \\
\text { zones }\end{array}$ & $\begin{array}{l}\text { Opacities appeared } \\
\text { after onset of } \\
\text { arthritis. No } \\
\text { change since }\end{array}$ & $\begin{array}{l}\text { M.B.C. } 134 \\
\text { litres/min. } \\
\text { E.S.R. 11-3 } \\
\text { mm. }\end{array}$ \\
\hline 4 & 48 & 50 & 5 & 3 & Moderate & Slight & 2 & $\begin{array}{l}\text { Predominantly } \\
\text { round }\end{array}$ & $\begin{array}{c}\text { Upper and } \\
\text { mid zones } \\
\text { bilateral }\end{array}$ & None & $\begin{array}{l}\text { B.P. } 210 / 120 \\
\text { Eczema wrist }\end{array}$ \\
\hline 5 & 33 & 34 & 5 & 4 & Slight & None & 3 & P.M.F. & Upper zones $_{\mathbf{R}>\mathrm{L}}$ & ", & Sputa negativ \\
\hline 6 & 51 & 54 & 5 & 2 & Moderate & Moderate & 1 & $\begin{array}{l}\text { Predominantly } \\
\text { round }\end{array}$ & $\begin{array}{l}\text { All zones } \\
\text { L }>\text { R }\end{array}$ & , & , \\
\hline 7 & 40 & 42 & 4 & 2 & , & None & $\mathbf{U} / \mathbf{R}$ & , & $\begin{array}{l}\text { All zones } \\
\text { bilateral }\end{array}$ & , & \\
\hline 8 & 47 & 50 & 5 & 2 & , & Slight & 1 &, & $\begin{array}{l}\text { Mid and lower } \\
\text { zones bilat- } \\
\text { eral }\end{array}$ & , & \\
\hline 9 & 47 & 52 & 7 & 2 & , & Moderate & $\begin{array}{c}3 \\
\text { (Sili- } \\
\text { cotic) }\end{array}$ & P.M.F. & $\begin{array}{l}\text { Upper and mid } \\
\text { zones } \\
\text { lateral }\end{array}$ & , & , \\
\hline 10 & 50 & 46 & 3 & 7 & Slight & Slight & $\begin{array}{c}\text { conci) } \\
2\end{array}$ & Resembles T.B. & $\begin{array}{l}\text { Upper zones } \\
\text { bilateral } \\
\text { ? cavity }\end{array}$ & $\begin{array}{l}\text { Opacities appeared } \\
\text { after onset of } \\
\text { arthritis. Slight } \\
\text { progression }\end{array}$ & , , , \\
\hline 11 & 54 & 59 & 8 & 3 & Moderate & Moderate & 1 & Mixed & $\begin{array}{c}\text { Mid and lower } \\
\text { zones } R>L\end{array}$ & None & \\
\hline $\begin{array}{l}12 \\
13\end{array}$ & $\begin{array}{l}38 \\
48\end{array}$ & $\begin{array}{l}37 \\
58\end{array}$ & $\begin{array}{r}2 \\
12\end{array}$ & $\begin{array}{l}3 \\
2\end{array}$ & $\begin{array}{l}\text { Slight } \\
\text { Severe }\end{array}$ & $\begin{array}{l}\text { None } \\
\text { Slight }\end{array}$ & $\begin{array}{l}3 \\
1\end{array}$ & $\begin{array}{l}\text { None } \\
\text { Mixed }\end{array}$ & $\underset{\mathrm{R}>\mathrm{L}}{\mathrm{Upe} \text { e } \mathrm{r} \text { and }}$ & None ${ }^{-}$ & \\
\hline 14 & 32 & 33 & 2 & 1 & Slight & None & 1 & Predominantly & $\begin{aligned} R & >L \\
\text { Mid and lower } & \end{aligned}$ & , & \\
\hline 15 & 39 & 37 & 2 & 4 & , & Slight & 1 & $\begin{array}{l}\text { Predominantly } \\
\text { round }+T . B .\end{array}$ & $\begin{array}{l}\text { All zones } \\
\mathbf{R}>\mathrm{L}\end{array}$ & $\begin{array}{c}\text { Opacities appeared } \\
\text { after onset of } \\
\text { arthritis; fairly } \\
\text { marked progres- } \\
\text { sion in first year }\end{array}$ & $\begin{array}{c}\text { Gastric lavag } \\
\text { positive fo } \\
\text { T.B. E.S.R } \\
27-10 \mathrm{~mm} \text {. }\end{array}$ \\
\hline 16 & 40 & 40 & 11 & 11 & Severe & , & $\begin{array}{l}3 \\
\text { (Sili- } \\
\text { cotic) }\end{array}$ & None & - & $\begin{array}{l}\text { Calcification in } \\
\text { silicotic nodules }\end{array}$ & \\
\hline 17 & 26 & 27 & 3 & 2 & Slight & , & $\mathbf{U} \mathbf{R}$ & Resembles T.B. & $\begin{array}{c}\text { All zones bi- } \\
\text { l a t e r a l } \\
\text { Cavity } R . \\
\text { upper zone }\end{array}$ & None & $\begin{array}{l}\text { Sputa negative } \\
\text { Died }\end{array}$ \\
\hline 18 & 52 & 49 & 4 & 7 & Moderate & Moderate & 2 & $\begin{array}{l}\text { Predominantly } \\
\text { round }\end{array}$ & $\begin{array}{l}\text { All zones bi- } \\
\text { lateral }\end{array}$ & $\begin{array}{l}\text { Opacities appeared } \\
\text { after onset of } \\
\text { arthritis. No } \\
\text { change since }\end{array}$ & Sputa negati \\
\hline 19 & 37 & 34 & 3 & 6 & Slight & None & 1 & Mixed & $\begin{array}{c}\text { Mid and lower } \\
\text { zones } L>R\end{array}$ & $\begin{array}{l}\text { Opacities appeared } \\
\text { after onset of } \\
\text { arthritis. No } \\
\text { change since }\end{array}$ & , \\
\hline 20 & 48 & 55 & 9 & 2 & Moderate & Severe & 0 & , & $\begin{array}{l}\text { All zones } \\
\mathbf{R}>\mathbf{L}\end{array}$ & No change & \\
\hline 21 & 52 & 56 & 11 & 6 & Severe & Slight & 2 & , & $\begin{array}{l}\text { Upper and } \\
\text { mid zones } \\
\text { bilateral }\end{array}$ & $\begin{array}{l}\text { Opacities smaller } \\
\text { and more irregu- }\end{array}$ & , \\
\hline 22 & 35 & 49 & 15 & 1 & Slight & , & 0 & $\begin{array}{l}\text { Predominantly } \\
\text { round }\end{array}$ & $\begin{array}{l}\text { Mid and lower } \\
\text { zones bilat- } \\
\text { eral }\end{array}$ & No change & , \\
\hline 23 & 28 & 24 & 1 & 5 & , & None & 3 & P.M.F. & Right upper & , , , & \\
\hline 24 & 37 & 34 & 2 & 5 & , & , & 2 & Mixed & $\begin{array}{l}\text { Upper and mid } \\
\text { zones bilat- } \\
\text { eral }\end{array}$ & $\begin{array}{l}\text { Opacities appeared } \\
\text { after onset of } \\
\text { arthritis. No } \\
\text { change since }\end{array}$ & , \\
\hline 25 & 35 & 31 & 2 & 6 & , & , & 3 & P.M.F. & $\begin{array}{l}\text { Right mid } \\
\text { zone }\end{array}$ & $\begin{array}{l}\text { change since } \\
\text { Opacities appeared } \\
\text { after onset of } \\
\text { arthritis. No } \\
\text { change since }\end{array}$ & \\
\hline 26 & 55 & 56 & 2 & 1 & , & Slight & 1 & Mixed & $\begin{array}{l}\text { Mid and lower } \\
\text { zones bilat- } \\
\text { eral }\end{array}$ & No change & \\
\hline
\end{tabular}


APPENDIX-cintinued

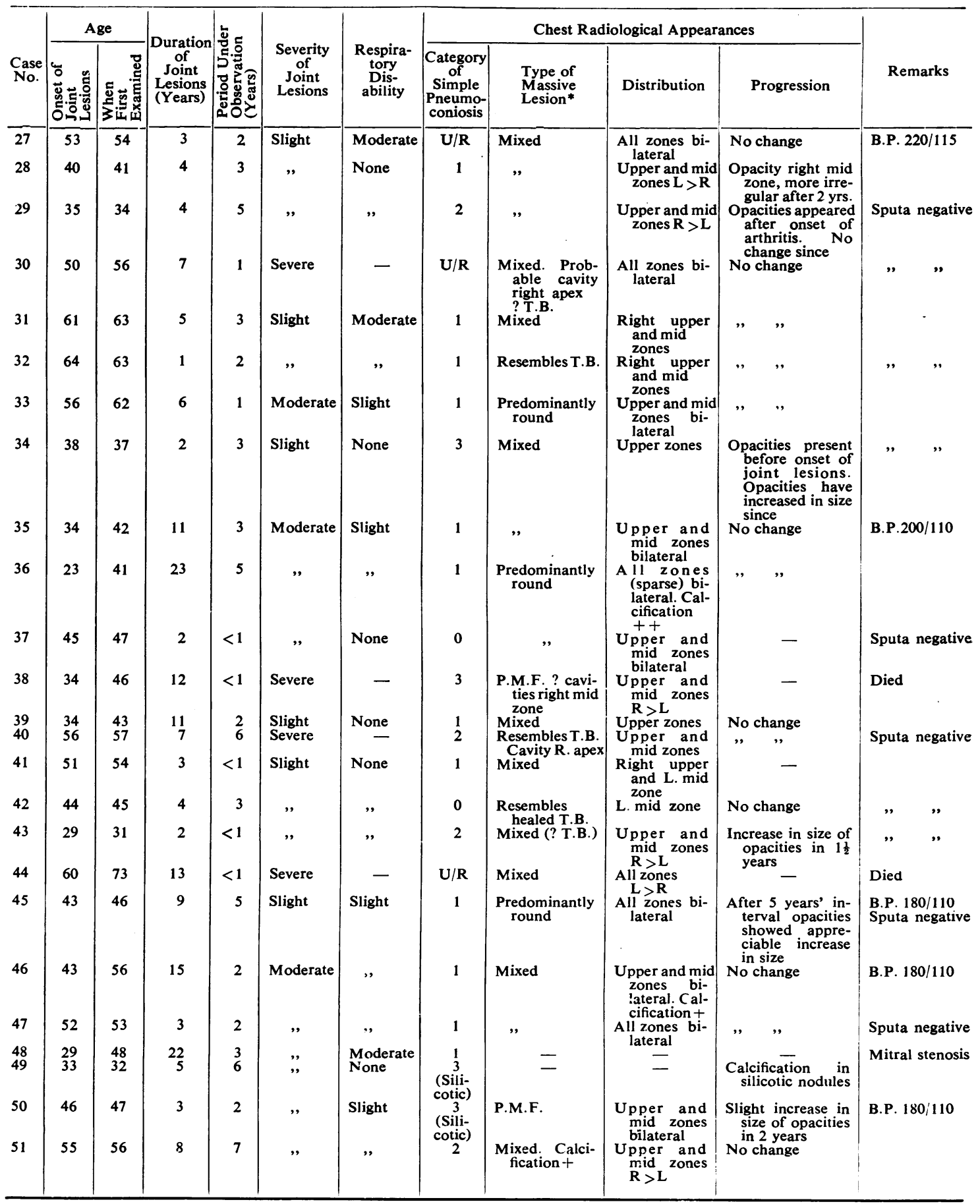

* See text for nomenclature. 